\title{
Effects of Whole-Body 50-Hz Magnetic Field Exposure on Mouse Leydig Cells
}

\author{
Zsolt Forgács $^{1, \star}$, Zoltán Somosy ${ }^{2}$, Györgyi Kubinyi ${ }^{2}$, Hanna Sinay ${ }^{2}$ \\ József Bakos ${ }^{2}$, György Thuróczy ${ }^{2}$, András Surján ${ }^{1}$, Aranka Hudák ${ }^{3}$, \\ Ferenc Olajos ${ }^{4}$, and Péter Lázár ${ }^{1}$ \\ ${ }^{1}$ National Institute of Chemical Safety, Budapest, Hungary; ${ }^{2 " N a t i o n a l ~ F r e d e r i c ~}$ \\ Joliot-Curie" Research Institute for Radiobiology and Radiohygiene, Budapest, Hungary; \\ ${ }^{3}$ Clinical Laboratory, National Institute of Occupational Health, Budapest, Hungary; \\ ${ }^{4}$ Second Department of Gynecology, Semmelweis University, Budapest, Hungary \\ E-mail: zforgacs@yahoo.com; forgacs@bigfoot.com
}

Received July 26, 2004; Accepted August 19, 2004; Published October 20, 2004

The main goal of this study was to evaluate the possible effect of whole-body magnetic field (MF) exposure on the steroidogenic capacity of Leydig cells in vitro. In four separate experiments, male CFLP mice were exposed to sinusoidal $50-\mathrm{Hz}, 100-\mu \mathrm{T}$ MF. The duration of exposure was $23.5 \mathrm{~h} /$ day over a period of 14 days. At the end of the exposure, interstitial (Leydig) cells were isolated from the testicles of the sham-exposed and exposed animals. The cells were cultured for $48 \mathrm{~h}$ in the presence or absence of 1, 10, or $100 \mathrm{mIU} / \mathrm{ml}$ human chorionic gonadotropin (hCG). The luteinizing hormone (LH) analog hCG was used to check the testosterone $(T)$ response of the sham-exposed controls and to evaluate the possible effect of the whole-body MF exposure on the steroidogenic capacity of Leydig cells in vitro. Testosterone content of the culture media and blood sera was measured by radioimmunoassay (RIA). In the cultures obtained from MFexposed animals, the hCG-stimulated T response was significanly higher $(p<0.01)$ compared with the sham-exposed controls, while the basal T production of cells and the level of serum $T$ remained unaltered. No MF exposure-related histopathological alterations were found in testicles, epididymes, adrenals, prostates, and pituitary glands. The MF exposure did not affect the animal growth rate and the observed hematologic and serum chemical variables.

Our results indicate a presumably direct effect of whole-body MF exposure on the hCG-stimulated steroidogenic response of mouse Leydig cells.

KEYWORDS: ELF magnetic fields, power-line frequency, testosterone, Leydig cell culture, radioimmunoassay, hCG, histology, hematology, serum chemistry

DOMAINS: microscopy, cell and tissue culture, endocrinology, hematology, reproduction, biophysics

\section{INTRODUCTION}

In the last decades, utilization of electricity has increased and diffused in both households and industries. The frequency of the current used in these systems is $0-300 \mathrm{~Hz}$. This frequency interval is termed ${ }^{*}$ Corresponding author. 
extremely low frequency magnetic field (ELF-MF), which is a nonionizing radiation having photon energy too weak to break the atomic bonds. One of the most important fields of research in this topic is the investigation of the possible biological effects of power-line frequency $(50 / 60 \mathrm{~Hz}) \mathrm{MF}$. At these frequencies, male and female reproductive functions have been proposed as possibly sensitive targets for the biological actions of MF. However, experimental data on male reproduction are quite limited and contradictory.

Kato et al.[1] reported that 6 weeks of nearly continuous exposure to circularly polarized $50-\mathrm{Hz} \mathrm{MF}$ at 1,5 , or $50 \mu \mathrm{T}$ flux densities did not change plasma testosterone (T) in rats. Margonato et al.[2] did not find any MF-induced morphologic and histologic changes in the testes of rats after prolonged exposure to a $50-\mathrm{Hz}$ MF of $5 \mu \mathrm{T}$. In another experiment, the same working group exposed rats for 8 months $(8 \mathrm{~h} /$ day, 5 days/week) to a $50-\mathrm{Hz}$ MF of 5 or $100 \mu \mathrm{T}$ and they also did not observed any MF-related alterations in testicular histology[3]. However, Picazo et al.[4] reported a significant increase in the size and weight of the testicles (due to an increase in the interstitial tissue) and elevated levels of serum $\mathrm{T}$ after a 10 -week exposure of $50-\mathrm{Hz} / 100-\mu \mathrm{T}$ MF. Sert et al.[5] also found increased $\mathrm{T}$ levels in rats that they left for 5 weeks, $3 \mathrm{~h} /$ day in a $50-\mathrm{Hz} / 0.8-\mathrm{mT}$ MF. In addition, statistical difference was found between the control and exposed animals with respect to head with lack of hook and isolated head type sperm. Besides this, they observed decreased spermatogenesis in some seminiferous tubules, congestion in blood vessels of the interstitium, and increases in interstitial edema and Sertoli cells. Al-Akhras et al.[6] observed a partly reversible reduction in male rat fertility after 90-day exposure to a 50-Hz MF of $25 \mu \mathrm{T}$. However, this working group did not find any MF exposure-related effects on the fertility of male mice at the same parameters of exposure[7].

Heredia-Rojas et al.[8] did not observe any meiotic chromosome aberrations in spermatocytes and any changes in sperm morphology in mice following a $60-\mathrm{Hz}, 2-\mathrm{mT}$ MF exposure for $72 \mathrm{~h}$ or 10 days $/ 8 \mathrm{~h}$ daily. However, Lee et al.[9] reported an increased apoptotic rate of germ cells and a decrement in the number of well-organized seminiferous tubules in mice after a continuous $60-\mathrm{Hz}, 0.5-$ or $1-\mathrm{mT} \mathrm{MF}$ exposure for 8 weeks. De Vita et al.[10] observed a statistically significant decrease in elongated spermatids obtained from rats 28 days after exposure to sinusoidal $50-\mathrm{Hz}, 1.7-\mathrm{mT}$ MF for $4 \mathrm{~h}$. The authors suggested a possible cytotoxic and/or cytostatic effect of the applied MF on differentiating spermatogonia.

In our previous experiments, we found that in vitro exposure to sinusoidal $50-\mathrm{Hz}, 100-\mu \mathrm{T}$ MF was able to stimulate the basal $\mathrm{T}$ production of primary mouse Leydig cell culture[11].

The main goal of this study was to evaluate the possible direct effect of whole-body $50-\mathrm{Hz} \mathrm{MF}$ exposure on the in vitro steroidogenic capacity of cultured Leydig cells.

\section{MATERIALS AND METHODS}

\section{Animals}

CFLP mice (HUMAN, Gödöllö, Hungary) weighing 32-37 g (8-9 weeks old) were kept in a room with a $12: 12$ light/dark photoperiod, temperature of $20-23^{\circ} \mathrm{C}$, and relative humidity of $50-60 \%$. In each experiment, 10-13 sham-exposed and another 10-13 exposed mice were kept in plastic cages and allowed free access to standard laboratory pellets (Altromin) and tap water. The MF exposure was carried out in four repeated experiments.

\section{Magnetic Field Exposure}

The sinusoidal, $50-\mathrm{Hz}$ MF was generated by a pair of double-wound coils connected to an internally developed, stabilized AC-current generator. The coils were embedded in molded epoxy resin to avoid vibration. The inner diameter of the coils was $42 \mathrm{~cm}$. The distance between the two parallel coils, mounted horizontally above and below the mouse cage, was $32 \mathrm{~cm}$. The orientation of MF was vertical[12]. The magnetic flux density was measured with a Hall detector-type MF sensor and monitor (Lakeshore M420) 
and was continuously monitored with and EMDEX II MF dosimeter. The flux density of the 50-Hz MF was $100 \mu \mathrm{T}$ (rms) with less than $\pm 3 \%$ inhomogeneity within the exposed animal chamber. The combined geomagnetic field was $48 \mu \mathrm{T}$ in the laboratory. The duration of exposure was $23.5 \mathrm{~h} /$ day over a period of 14 days. The daily 0.5 -h breaks were necessary for cleaning cages and feeding.

Body weights were recorded on the first and the last day of the treatment. Following the termination of exposure, between 10:30 and 11:00 a.m., mice were anesthetized with $60 \mathrm{mg} / \mathrm{kg}$ ip. pentobarbital (RhonePoulenc Rorer, Vitry sur Seine, France) and testicles, epididymes, adrenals, prostates, and pituitary glands were removed and blood samples were taken. After surgery, the animals were overdosed with pentobarbital.

\section{Interstitial Cell Preparation and Incubation}

Interstitial cells were prepared and cultured from the right testicles of the animals. (The left testicles were used for histology.) For isolation of interstitial cells by mechanical dissociation without enzyme treatment, the method of Stoklosowa[13] was used with some modification, as described earlier[14]. In each experiment, interstitial cells were isolated and collected in two blocks: one obtained from shamexposed and another from the exposed animals. These mixtures of interstitial cells were diluted to $10^{6}$ cells/ml in Eagle's Modified Essential Medium (EMEM; Flow Laboratories, Irvine, Ayrshire, U.K.) supplemented with 10\% Fetal Bovine Serum (FBS; Gibco BRL), $100 \mathrm{IU} / \mathrm{ml}$ penicillin, and $100 \mu \mathrm{g} / \mathrm{ml}$ streptomycin (Sigma Chemical Co., St. Louis, MO). The cell suspensions were plated (with final volume of $500 \mu \mathrm{l} /$ well) into sterile 24-well plates (Corning Glassworks, Corning, NY). Leydig cells were identified by the histochemical reaction for $3 \beta$-hydroxisteroid dehydrogenase $(3 \beta$-HSD) enzyme[15,16]. In brief, cells were incubated for $3.5 \mathrm{~h}$ at $34^{\circ} \mathrm{C}$ in the culture medium containing of $0.6 \mathrm{mmol} / 1$ dehydroisoandrosterone (DHA; Sigma), $0.6 \mathrm{mmol} / 1$ nicotinic acid adenine dinucleotide (NAD; Sigma), $0.2 \mathrm{mmol} / 1$ nitro blue tetrazolium (NBT; Sigma), and 7\% propylene glycol. The percentage of $3 \beta$-HSD positive cells was at least $70 \%$. To assess viability prior to adding FBS to the culture medium, samples were taken and stained with trypan blue solution (Sigma) and the cells were counted in a hemocytometer. The intersitial cells were cultured in the presence or absence of 1,10 , or $100 \mathrm{mIU} / \mathrm{ml}$ human chorionic gonadotropin (hCG; Choriogonin; Richter, Budapest, Hungary). The luteinizing hormone (LH) analog hCG was used to check the T response of the sham-exposed controls and to evaluate the possible effect of the in vivo MF exposure on the steroidogenic capacity of Leydig cells in vitro. Cell cultures were maintained for $48 \mathrm{~h}$ at $34^{\circ} \mathrm{C}$ under a humidified atmosphere of $95 \%$ air $/ 5 \% \quad \mathrm{CO}_{2}$. Following the incubation, the aliquots of the culture medium were centrifuged and the supernatant was collected and frozen at $-20^{\circ} \mathrm{C}$ until $\mathrm{T}$ determination by radioimmunoassay (RIA).

\section{Testosterone Radioimmunoassay}

Quantification of T directly from aliquots of the cell culture media was performed by RIA. In addition, blood samples were taken from randomly selected animals to check the T levels of blood sera[1,2,6,7]. $\left[{ }^{3} \mathrm{H}\right]$-testosterone (3.74 TBq/mmol) was obtained from Amersham, Buckinghamshire, U.K. The T standard and antiserum were kindly donated by Dr. Tibor Fehér (Semmelweis Medical School, $1^{\text {st }}$ Department of Internal Medicine). The inter- and intra-assay coefficient of variations were 9.4 and 6.5\%, respectively. Cross-reactivity with $5 \alpha$-dihydroxytestosterone was $7.9 \%$.

\section{Histological Techniques}

Testes (left), epididymes, adrenals, prostates, and pituitary glands were fixed in buffered formol saline for histological examination. These tissues were dehydrated in ethanol, embedded in paraffin wax, and stained with hematoxylin and eosin. 


\section{Hematology}

Blood was taken from aorta, collected in plastic Eppendorf tubes containing $\mathrm{K}_{3}$ EDTA. White (WBC) and red (RBC) blood cells counts, hemoglobine concentration (HGB), volume of packed red cells (VPRC), and platelets (PLT) were determined using the Animal Blood Counter Vet abc ${ }^{\mathrm{TM}}$ (Roche).

\section{Serum Chemistry}

At sacrifice, free-flowing blood was collected in plastic Eppendorf tubes. After centrifugation, serum was removed and the samples were then analyzed for serum alkaline phosphatase, glutamic-oxaloacetic transaminase (GOT), glutamic-pyruvic transaminase (GPT), cholesterol, and triglycerides by an auto analyzer instrument (A.L. Instruments, France).

\section{Statistics}

The data were analyzed by Student's t-test and ANOVA using GraphPad Prism 3.01 computer software. To eliminate heterogeneity of variance among the data of experiments performed at different times, $\mathrm{T}$ levels of the culture media were expressed in percent of sham-exposed, in vitro $100 \mathrm{mIU} / \mathrm{ml} \mathrm{hCG-}$ stimulated controls. A value of $p<0.05$ was considered to be significant.

\section{RESULTS}

\section{Testosterone Production of Interstitial Cell Culture}

The Leydig cells used in all experiments were viable ( $>90 \%$ viability; checked by trypan blue exclusion test) and steroidogenically active. The sham-exposed mean 100-mIU/ml hCG-stimulated $\mathrm{T}$ response (control, 100\%) was $245.21 \pm 35.92 \mathrm{ng} / 10^{6}$ cells. In the Leydig cells obtained from animals subjected to MF exposure, a significant elevation in hCG-stimulated T response was seen over a 48 -h culture, while the basal $\mathrm{T}$ production and initial cell yield remained unaltered (Fig. 1). No MF exposure-related alteration was observed by phase contrast microscopy in cell size, attachment, and density of the 48-h semiconfluent monolayers.

\section{Serum Testosterone}

Concentration of serum $T$ was also checked in randomly selected animals $(n=19)$. The mean $( \pm \operatorname{SEM}) T$ level of the exposed animals $(350.26 \pm 47.40 \mathrm{pg} / \mathrm{ml})$ was found not to be significantly different from the sham-exposed controls $(364.89 \pm 40.88 \mathrm{pg} / \mathrm{ml})$.

\section{Histology}

No MF exposure-related histopathological alterations were found in testicles, epididymes, adrenals, prostates, and pituitary glands.

\section{Body Weight}

There was no significant difference in the body weights of exposed animals compared to the shamexposed controls on the first and the last day of the exposure. 


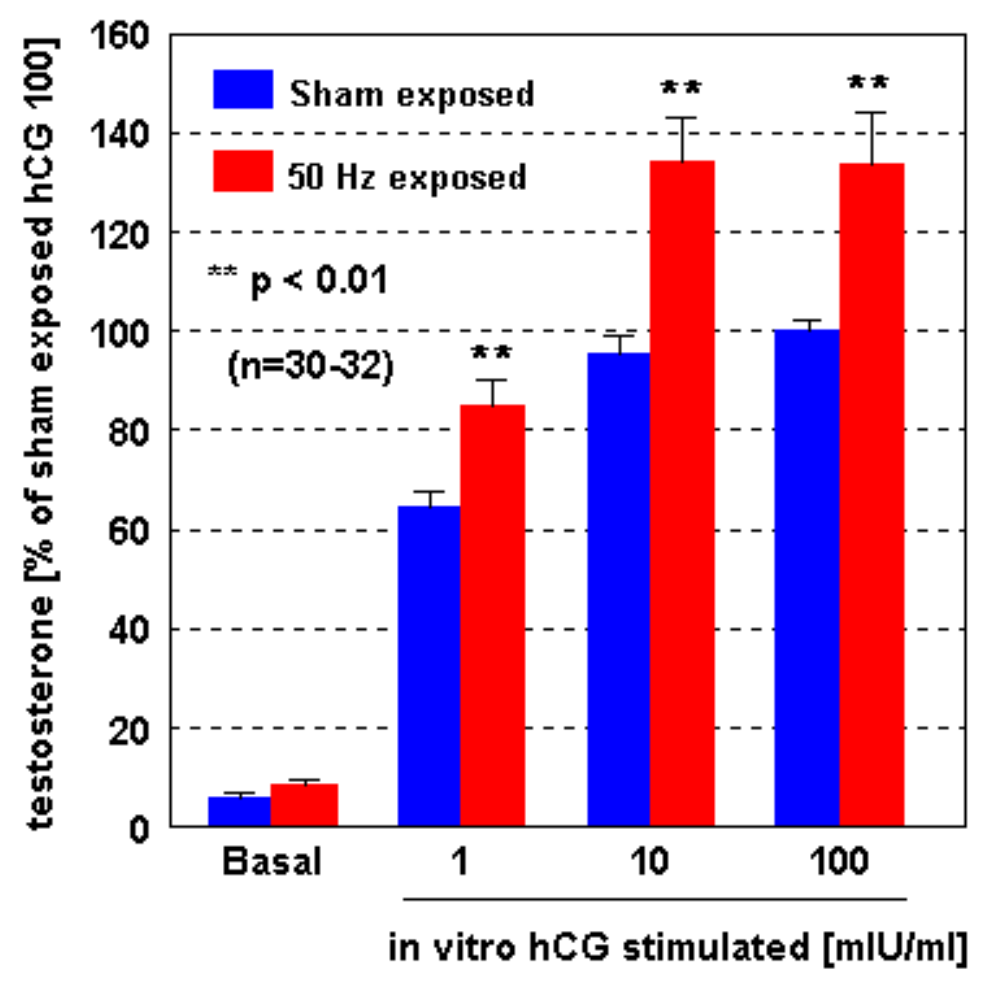

FIGURE 1. Effect of whole-body $50-\mathrm{Hz}$ MF exposure on the basal or in vitro hCGstimulated $\mathrm{T}$ response of 48 -h mouse Leydig cell culture. Bar values represent the mean $( \pm \mathrm{SEM}) \mathrm{T}$ production as percent of sham-exposed, in vitro $100-\mathrm{mIU} / \mathrm{ml}$ hCGstimulated cells $(\mathrm{n}=30-32)$ determined in four independent experiments. The statistical difference from sham-exposed, $100-\mathrm{mIU} / \mathrm{ml}$ hCG-stimulated control is indicated by $* *(p<0.01)$.

\section{Hematology}

The hematologic variables (mean $\pm \mathrm{SEM}$ ) of exposed and sham-exposed mice are summarized in Table 1. No statististical difference was found between exposed and sham-exposed animals.

\section{Serum Chemistry}

The mean values ( \pm SEM) of alkaline phosphatase, GOT, GPT, cholesterol, and triglycerides for exposed and sham-exposed mice are shown in Table 2. Statistical analysis did not give evidence of any significant difference between the two groups. 
TABLE 1

Mean Values \pm SEM of Blood Variables

\section{\begin{tabular}{|l|l|l}
\hline Blood variables & Sham-Exposed & $50 \mathrm{~Hz}$-exposed
\end{tabular}}

\begin{tabular}{|ll|rc|rr|}
\hline WBC & {$\left[10^{3} / \mu l\right]$} & $3.15 \pm 0.33$ & $(21)$ & $3.77 \pm 0.23$ & $(19)$ \\
\hline RBC & {$\left[10^{6} / \mu l\right]$} & $8.58 \pm 0.12$ & $(20)$ & $8.98 \pm 0.10$ & $(19)$ \\
\hline HGB $[\mathrm{g} / \mathrm{dl}]$ & $13.00 \pm 0.17$ & $(21)$ & $13.31 \pm 0.15$ & $(19)$ \\
\hline VPRC & {$[\%]$} & $41.62 \pm 0.55$ & $(21)$ & $41.21 \pm 0.50$ & $(19)$ \\
\hline PLT & {$\left[10^{3} / \mu l\right]$} & $756.30 \pm 19.92$ & $(20)$ & $745.10 \pm 25.01$ & $(19)$ \\
\hline
\end{tabular}

WBC, RBC, HGB, VPRC, and PLT in sham-exposed and 50-Hz-exposed mice; ( ) = number of animals.

TABLE 2

Mean Values \pm SEM of Serum Chemistry

\begin{tabular}{|ll|rr|rr|}
\hline \multicolumn{1}{l}{ Serum chemistry } & \multicolumn{2}{c|}{ Sham Exposed } & \multicolumn{2}{c|}{ 50 Hz-exposed } \\
\begin{tabular}{|ll|rl|rl|}
\hline Alk. phosph. & {$[\mathrm{U} / \mathrm{l}]$} & $404.20 \pm 22.45$ & $(21)$ & $365.20 \pm 20.42$ & $(16)$ \\
\hline SGOT & {$[\mathrm{U} / \mathrm{l}]$} & $178.80 \pm 10.70$ & $(24)$ & $175.10 \pm 11.36$ & $(26)$ \\
\hline SGPT & {$[\mathrm{U} / \mathrm{l}]$} & $52.25 \pm 3.07$ & $(25)$ & $61.94 \pm 4.22$ & $(26)$ \\
\hline Cholesterol & {$[\mathrm{mmol} / \mathrm{l}]$} & $3.00 \pm 0.16$ & $(15)$ & $2.84 \pm 0.11$ & $(25)$ \\
\hline Triglycerides & {$[\mathrm{mmol} / \mathrm{l}]$} & $0.90 \pm 0.09$ & $(16)$ & $1.13 \pm 0.11$ & $(16)$ \\
\hline
\end{tabular}
\end{tabular}

SGOT = serum glutamic-oxaloacetic transaminase; SGPT = serum glutamic-pyruvic transaminase; $($ ) = number of animals.

\section{DISCUSSION}

In toxicological experiments, in vitro measures of $\mathrm{T}$ production of Leydig cells seem to be more sensitive than in vivo indicators of testicular damage[17]. Determination of the LH- or hCG-stimulated T response of cells improves the sensitivity of this method.

Physiological $\mathrm{T}$ production in male vertebrates is stimulated by $\mathrm{LH}$ (or its analog hCG) through interaction with specific receptor located on the Leydig cell plasma membrane. Hormone-receptor interaction stimulates the classical second messenger pathway involved in steroidogenesis: adenylate cyclase - cAMP - protein kinase A[18]. While cAMP is a second messenger for LH in the control of steroidogenesis, other signaling systems exist that are potentially equally effective in controlling steroidogenesis. In addition, the action of cAMP requires other signaling pathways involving $\mathrm{Ca}^{2+}$ and $\mathrm{Cl}^{-}$, as well as arachidonic acid and its lipoxygenase products[19].

Our results indicate an elevated hCG-stimulated $\mathrm{T}$ response of Leydig cell cultures obtained from whole-body MF-exposed mice, while the basal $\mathrm{T}$ production of cells and the serum $\mathrm{T}$ level of the animals remained unaltered. These data suggest a presumably direct effect of whole-body MF exposure on Leydig cells. These results are in agreement with our previous findings about the effect of in vitro MF exposure on $\mathrm{T}$ response of mouse Leydig cells[11].

The mechanism of action of the applied MF exposure cannot be discerned from present results. The MF exposure might alter the sensitivity and/or density of LH receptors on the surface of the cell membrane of Leydig cells. It is known that the initial biochemical or metabolic state of the cell membrane, as well as the functional and supramolecular organization of its specific regions (cell contact areas, receptors), are sensitive targets of electric and electromagnetic field (EMF) exposures[20,21,22,23,24]. In vitro MF experiments have shown that signal transduction in receptor- 
regulated cells is interfered by MF exposure. This was first noted at receptor level in bone cells and the proposed mechanism was that MF caused changes in receptor binding and/or activation[25]. In other experiments, MF reduced the reactivity of central dopamine $\mathrm{D}(1)$ receptor in rats[26], modulated serotonin (5HT1A) receptor binding to a radioactive agonist in rats[27], and increased the expression of some genes relating to cytokine receptors in HL60 cells[28].

Second messengers of signal transduction processes, mainly cAMP and $\mathrm{Ca}^{2+}$, also seem to play a decisive role in this effect of MF exposure on steroidogenesis. A possible mechanism of action on steroidogenesis may be associated with the alterations in cAMP content and intercellular communication may be induced by the applied MF.

Schimmelpfeng et al.[29] found increased cAMP content and gap junction-mediated intercellular communication after $5 \mathrm{~min}$ of exposure to $50-\mathrm{Hz}, 2-\mathrm{mT}$ MF in monolayers of SV40-Swiss-3T3 mouse fibroblasts at intermediate cell density.

MF exposure can alter the local $\mathrm{Ca}^{2+}$ concentration in different types of cells[30,31] and it is able to enhance the expression of voltage-gated $\mathrm{Ca}^{2+}$ channels on plasma membrane of the exposed cells[32]. It is known that $\mathrm{Ca}^{2+}$ signaling is the biological main target of MF because it has extreme sensitivity for coherent excitation by very low field energies within specific amplitude and frequency windows[33].

The results of our experiments show that whole-body MF exposure is able to increase the steroidogenic responsiveness of mouse Leydig cells to LH at a flux density that does not elicit any histopathological alterations in the investigated organs or changes in hematology and serum chemistry. The level of serum $\mathrm{T}$ was unaltered probably due to the feedback mechanisms of hypothalamic-pituitarygonadal axis.

Further investigations are required to clarify the subcellular action of applied MF in Leydig cells, as well as to establish the biological significance of this phenomenon.

\section{ACKNOWLEDGMENTS}

Thanks are due to Mrs. Mária Szívós and Mrs. Erika Sklánitz for their excellent technical assistance. The study was supported by research grants from the National Scientific Research Fund (OTKA No. T 034957) and the Committee for Health Studies Grant (ETT 160/2003) of the Ministry of Health, Social and Family Affairs in Hungary.

\section{REFERENCES}

1. Kato, M., Honma, K., Shigemitsu, T., and Shiga, Y. (1994) Circularly polarized, sinusoidal, 50 Hz magnetic field exposure does not influence plasma testosterone levels of rats. Bioelectromagnetics 15, 513-518.

2. Margonato, V., Nicolini, P., Conti, R., Zecca, L., Veicsteinas, A., and Cerretelli, P. (1995) Biologic effects of prolonged exposure to ELF electromagnetic fields in rats. II. $50 \mathrm{~Hz}$ magnetic fields. Bioelectromagnetics 16, 343355 .

3. Zecca, L., Mantegazza, C., Margonato, V., Cerretelli, P., Caniatti, M., Piva, F., Dondi, D., and Hagino, N. (1998) Biological effects of prolonged exposure to ELF electromagnetic fields in rats. III. $50 \mathrm{~Hz}$ electromagnetic fields. Bioelectromagnetics 19, 57-66.

4. $\quad$ Picazo, M.L., Demiguel, M.P., Leyton, V., Franco, P., Varela, L., Paniagua, R., and Bardasano, J.L. (1995) Longterm effects of ELF magnetic-fields on the mouse testis and serum testosterone levels. Electro-Magnetobiology 14, $127-134$.

5. Sert, C., Akdag, M.Z., Bashan, M., Buyukbayram H., and Dasdag, S. (2002) ELF magnetic field effects on fatty-acid composition of phospholipid fraction and reproduction of rat's testes. Electromagn. Biol. Med. 21, 19-29.

6. Al-Akhras, M.A., Elbetieha, A., Hasan, M.K., Al-Omari, I., Darmani, H., and Albiss, B. (2001) Effects of extremely low frequency magnetic field on fertility of adult male and female rats. Bioelectromagnetics 22, 340-344.

7. Elbetieha, A., Al-Akhras, M.A., and Darmani, H. (2002) Long-term exposure of male and female mice to $50 \mathrm{~Hz}$ magnetic field: effects on fertility. Bioelectromagnetics 23, 168-172.

8. Heredia-Rojas, J.A., Caballero-Hernandez, D.E., Rodriguez-de la Fuente, A.O., Ramos-Alfano, G., and RodriguezFlores, L.E. (2004) Lack of alterations on meiotic chromosomes and morphological characteristics of male germ cells in mice exposed to a $60 \mathrm{~Hz}$ and $2.0 \mathrm{mT}$ magnetic field. Bioelectromagnetics 25, 63-68.

9. Lee, J.S., Ahn, S.S., Jung, K.C., Kim, Y.W., and Lee, S.K. (2004) Effects of $60 \mathrm{~Hz}$ electromagnetic field exposure on testicular germ cell apoptosis in mice. Asian J. Androl. 6, 29-34.

10. De Vita, R., Cavallo, D., Raganella, L., Eleuteri, P., Grollino, M.G., and Calugi, A. (1995) Effects of $50 \mathrm{~Hz}$ magnetic 
fields on mouse spermatogenesis monitored by flow cytometric analysis. Bioelectromagnetics 16, 330-334.

11. Forgács, Zs., Thuróczy, Gy., Paksy, K., and Szabó, D.L. (1998) Effect of sinusoidal 50 Hz magnetic field on the testosterone production of mouse primary Leydig cell culture. Bioelectromagnetics 19, 429-431.

12. Kubinyi, Gy., Thuróczy, Gy., Sinay, H., and Szabó, D.L. (1998) Magnetic field and the initial phase of the protein sythesis in newborn and adult mice. Electro-Magnetobiology 17, 161-169.

13. Stoklosowa, S. (1982) Tissue culture of gonadal cells. Acta Biol. Hung. 33, 367-379.

14. Forgács, Zs., Paksy, K., Lázár, P., and Tátrai, E. (1998) Effect of $\mathrm{Ni}^{2+}$ on the testosterone production of mouse primary Leydig cell culture. J. Toxicol. Environ. Health 55, 213-224.

15. Joshi, N.J., Moodbidri, S.B., and Nandedkar, T.D. (1987) Inhibition of $\Delta^{5}-3 \beta$ hydroxysteroid dehydrogenase activity in pre-implantation mouse embryos and their implantation by sheep ovarian follicular fluid peptide. Acta Endocrinol. (Copenhagen) 115, 183-188.

16. Steinberger, E., Steinberger, A., and Vilar, O. (1966) Cytochemical study of $\Delta^{5}-3 \beta$ - hydroxysteroid dehydogenase in testicular cells grown in vitro. Endocrinology 79, 406-410.

17. Phelps, P.V. and Laskey, J.W. (1989) Comparison of age-related changes in in vivo and in vitro measures of testicular steroidogenesis after acute cadmium exposure in the Sprague-Dawley rat. J. Toxicol. Environ. Health 27, 95-105.

18. Dufau, M.L. (1988) Endocrine regulation and communicating functions of the Leydig cell. Annu. Rev. Physiol. 50, 483-508.

19. Cooke, B.A. (1999) Signal transduction involving cyclic AMP-dependent and cyclic AMP-independent mechanisms in the control of steroidogenesis. Mol. Cell. Endocrinol. 151, 25-35.

20. Bordiushkov, Iu.N., Goroshinskaia, I.A., Frantsiiants, E.M., Tkacheva, G.N., Gorlo, E.I., and Neskubina, I.V. (2000) [Structural-functional changes in lymphocyte and erythrocyte membranes after exposure to alternating magnetic field.] Vopr. Med. Khim. 46, 72-80.

21. Massot, O., Grimaldi, B., Bailly, J.M., Kochanek, M., Deschamps, F., Lambrozo, J., and Fillion, G. (2000) Magnetic field desensitizes 5-HT(1B) receptor in brain: pharmacological and functional studies. Brain Res. 858, $143-150$.

22. Muehsam, D.J. and Pilla, A.A. (1999) The sensitivity of cells and tissues to exogenous fields: effects of target system initial state. Bioelectrochem. Bioenerg. 48, 35-42.

23. Santoro, N., Lisi, A., Pozzi, D., Pasquali, E., Serafino, A., and Grimaldi, S. (1997) Effect of extremely low frequency (ELF) magnetic field exposure on morphological and biophysical properties of human lymphoid cell line (Raji). Biochim. Biophys. Acta 1357, 281-290.

24. Fitzsimmons, R.J., Ryaby, J.T., Magee, F.P, and Baylink, D.J. (1995) IGF-II receptor number is increased in TE-85 osteosarcoma cells by combined magnetic fields. J. Bone Miner. Res. 10, 812-819.

25. Luben, R.A., Cain, C.D., Chen, M.C.-Y., Rosen, D.M., and Adey, W.R. (1982) Effects of electromagnetic stimuli on bone and bone cells in vitro: inhibition of responses to parathyroid hormone by low-energy low-frequency fields. Proc. Natl. Acad. Sci. U. S. A. 79, 4180-4184.

26. Sieron, A., Brus, R., Szkilnik, R., Plech, A., Kubanski, N., and Cieslar, G. (2001) Influence of alternating low frequency magnetic fields on reactivity of central dopamine receptors in neonatal 6-hydroxydopamine treated rats. Bioelectromagnetics 22, 479-486.

27. Johnson, M.T., McCullough, J., Nindl, G., and Chamberlain, J.K. (2003) Autoradiographic evaluation of electromagnetic field effects on serotonin (5HT1A) receptors in rat brain. Biomed. Sci. Instrum. 39, 466-470.

28. Zhou, J., Li, C., Yao, G., Chiang, H., and Chang, Z. (2002) Gene expression of cytokine receptors in HL60 cells exposed to a $50 \mathrm{~Hz}$ magnetic field. Bioelectromagnetics 23, 339-346.

29. Schimmelpfeng, J., Stein, J.C., and Dertinger, H. (1995) Action of $50 \mathrm{~Hz}$ magnetic fields on cyclic AMP and intercellular communication in monolayers and spheroids of mammalian cells. Bioelectromagnetics 16, 381-386.

30. Barbier, E., Dufy, B., and Veyret, B. (1996) Stimulation of $\mathrm{Ca}^{2+}$ influx in rat pituitary cells under exposure to a $50 \mathrm{~Hz}$ magnetic field. Bioelectromagnetics 17, 303-311.

31. Aldinucci, C., Garcia, J.B., Palmi, M., Sgaragli, G., Benocci, A., Meini, A., Pessina, F., Rossi, C., Bonechi, C., and Pessina, G.P. (2003) The effect of exposure to high flux density static and pulsed magnetic fields on lymphocyte function. Bioelectromagnetics 24, 373-379.

32. Grassi, C., D'Ascenzo, M., Torsello, A., Martinotti, G., Wolf, F., Cittadini, A., and Azzena, G.B. (2004) Effects of 50 $\mathrm{Hz}$ electromagnetic fields on voltage-gated $\mathrm{Ca}^{2+}$ channels and their role in modulation of neuroendocrine cell proliferation and death. Cell Calcium 35, 307-315.

33. Gartzke, J. and Lange, K. (2002) Cellular target of weak magnetic fields: ionic conduction along actin filaments of microvilli. Am. J. Physiol. Cell. Physiol. 283, C1333-1346.

\section{This article should be referenced as follows:}

Forgács, Z., Somosy, Z., Kubinyi, G., Sinay, H., Bakos, J., Thuróczy, G., Surján, A., Hudák, A., Olajos, F., and Lázár, P. (2004) Effects of whole-body 50-Hz magnetic field exposure on mouse Leydig cells. TheScientificWorldJOURNAL 4(S2), 8390. 

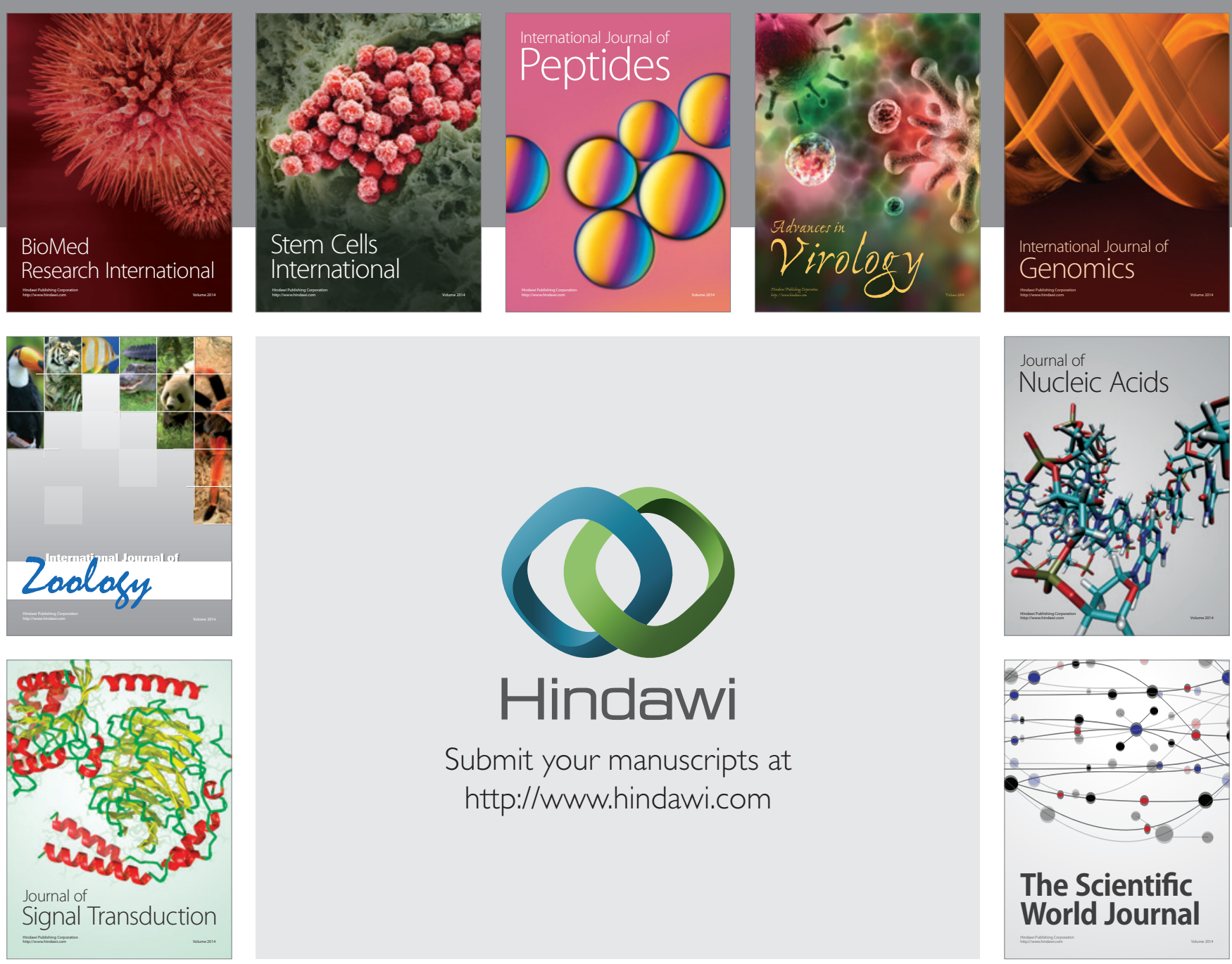

Submit your manuscripts at

http://www.hindawi.com
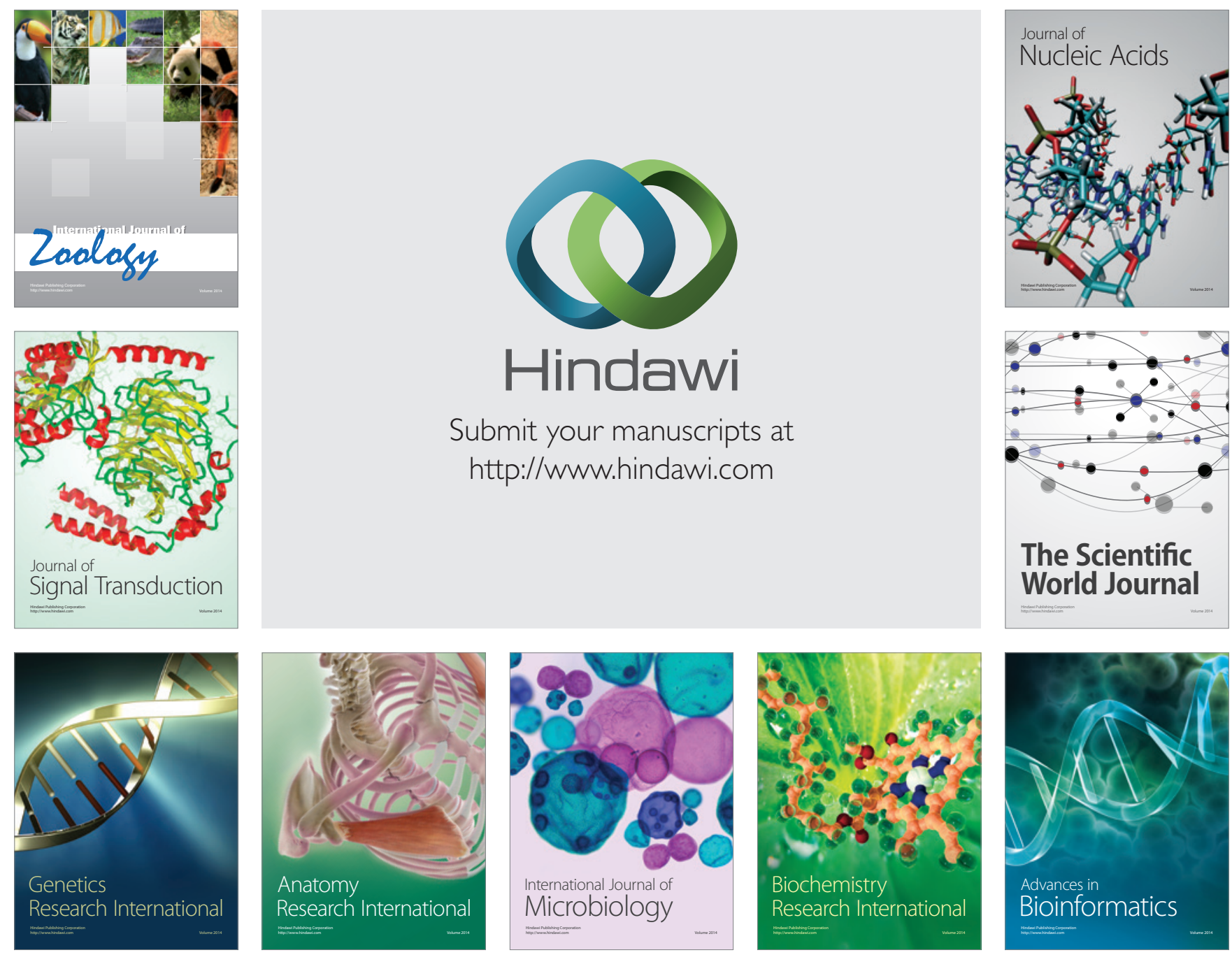

The Scientific World Journal
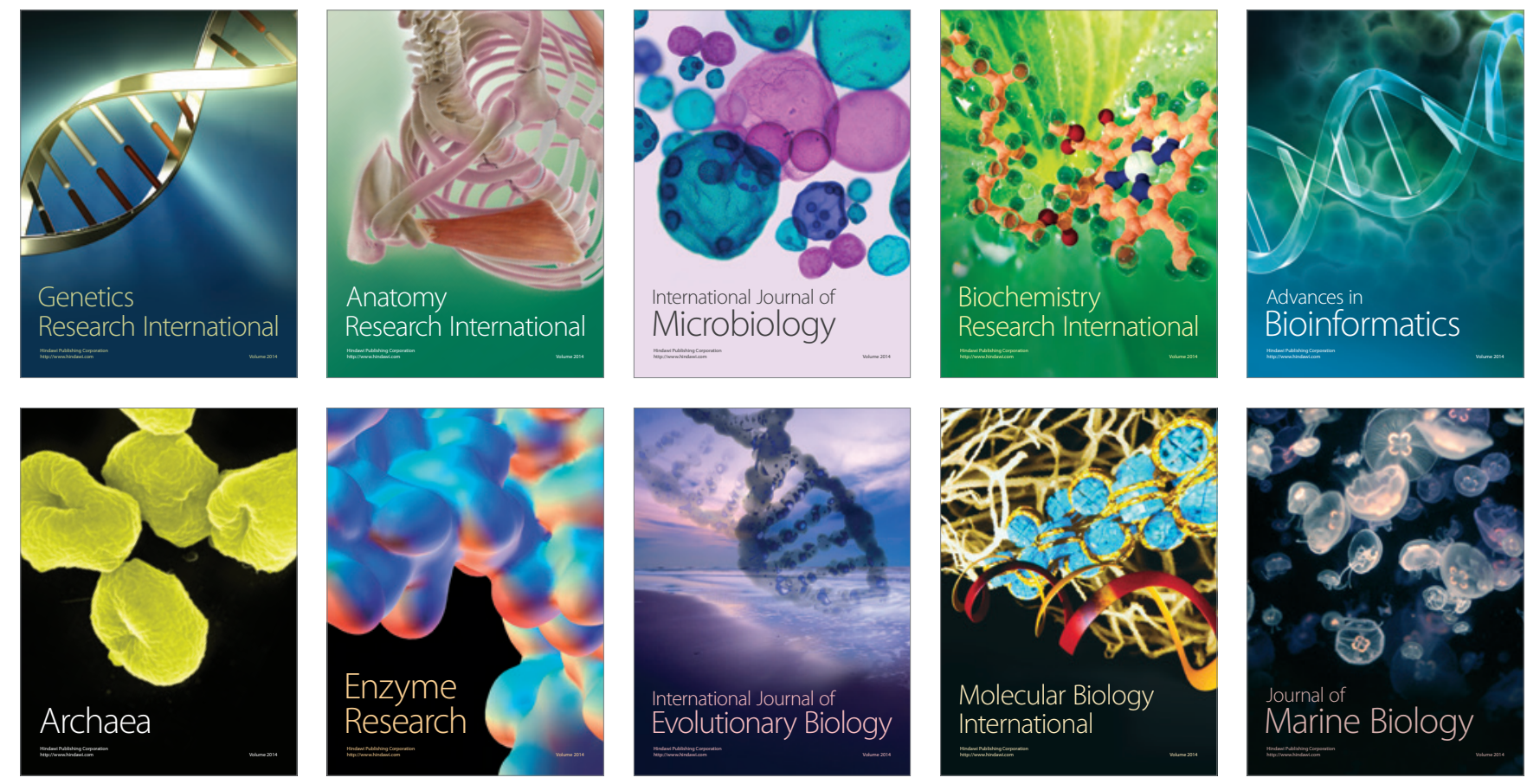